\title{
Isolation and Characterization of Styryllactone of Goniothalamus ridleyi
}

(Pemencilan dan Pencirian Stirillakton Goniothalamus ridleyi)

\author{
SAMSIAH JUSOH, ZURIATI ZAKARIA, FASIHUDDIN B. AHMAD \& LAILY B. DIN*
}

\section{ABSTRACT}

Phytochemical studies were conducted on the stem bark, stem, root and fruit of Goniothalamus ridleyi (Annonaceae) collected at Post Brooke, Gua Musang, Kelantan, Malaysia. Extraction using organic solvent followed by extensive purification using standard procedure afforded an epoxystyryllactone, 5-acetoxyisogoniothalamin oxide (1) from the stem bark and fruit; a styryllactone, 5-acetoxygoniothalamin (2) and a styrylpyrone, dehydrogoniothalamin (3) from the stem and root; a styryllactone, 5-hydroxygoniothalamin (4) from the root and styrylpyrone as well as goniothalamin (5) from the fruit. These compounds were characterized using spectroscopic techniques.

Keywords: Annonaceae; goniothalamin derivatives; Goniothalamus; NMR

\section{ABSTRAK}

Kajian fitokimia telah dijalankan ke atas kulit batang, batang, akar dan buah Goniothalamus ridleyi (Annonaceae) yang diperoleh dari Post Brooke, Gua Musang, Kelantan, Malaysia. Pengekstrakan menggunakan pelarut organik diikuti dengan pemisahan ekstensif menggunakan prosedur piawai menghasilkan epoksistirillakton, 5-asetoksiisogoniotalamin oksida (1) daripada kulit batang dan buah; stirillakton, 5-asetoksigoniotalamin (2) dan stirilpiron, dehidrogoniotalamin (3) daripada batang dan akar; stirillakton, 5-hidroksigoniotalamin (4) daripada akar dan stirilpiron manakala goniotalamin (5) daripada buah. Sebatian-sebatian ini dikenal pasti menggunakan teknik spektroskopi.

Kata kunci: Annonaceae; Goniothalamus; NMR; terbitan goniothalamin

\section{INTRODUCTION}

The genus Goniothalamus (Annonaceae) is an archaic shrub or treelets which grow in shady primary rainforest of tropical Asia (Wiart 2007). Goniothalamus ridleyi is a sub-canopy tree which can grow up to 7-15 m tall and $8-20 \mathrm{~cm}$ diameter. Stipules are absent and the leaves are alternate, simple and penni-veined. The size of the flower petals are approximately $5-10 \mathrm{~cm}$ long, reddish-brown and are placed in apocarps containing several seeds. This plant could be found in undisturbed forests up to $500 \mathrm{~m}$ in altitude, usually on hillsides and ridges. In the secondary forests, it is usually present as a pre-disturbance remnant. The bark decoction is used to treat stomach-ache (Mat-Salleh \& Latiff 2002). Phytochemical studies on Goniothalamus spp. showed that the presence of interesting secondary metabolites particularly styryllactones and annonaceous acetogenins and alkaloids. All the secondary metabolites isolated from this genera especially styryllactone and acetogenin showed significant cytotoxicity against several human cell lines. In the previous study on $G$. ridleyi, goniothalamin, goniothalamin oxide and isoaltholacton have been isolated (Ee et al. 1999). The objectives of this research was to isolate and characterize secondary metabolites from different parts of $G$. ridleyi and to investigate the correlation of these compounds in the plant.

\section{MATERIALS AND METHODS}

\section{PLANT}

G. ridleyi was collected from Post Brooke, Gua Musang, Kelantan, Malaysia and separated into stem bark, stem, root and fruit. The samples were oven dried at $50^{\circ} \mathrm{C}$ and ground to powder form prior to extraction. This species has been identified by a botanist, Dr. Shamsul Khamis (UPM). The voucher specimen of G. ridleyi (SK1739/10) was deposited at Herbarium Universiti Putra Malaysia (UPM), Serdang.

\section{EXTRACTION AND ISOLATION}

The extraction of samples were carried out using three different solvent i.e. hexane, chloroform and methanol, which afforded three crude extracts. Each crude extract was separated using vacuum liquid chromatography (VLC, if the extract was more than $3 \mathrm{~g}$ ), column chromatography (CC) and preparative thin layer chromatography (PTLC). The purification of the crude extracts afforded 5-acetoxyisogoniothalamin oxide (1), 5-acetoxygoniothalamin (2), dehydrogoniothalamin (3), 5-hydroxygoniothalamin (4) and goniothalamin (5).

The chloroform crude extract of the stem bark of G. ridleyi ( $5 \mathrm{~g}$ ) was separated using VLC using mixture of chloroform, ethyl acetate and as mobile phase. 
Fractions 4-11 which showed similar profile based on thin layer chromatography (TLC) were combined and further separated using $\mathrm{CC}$ with hexane, chloroform and methanol as mobile phase. Fractions 115-118 were combined and further separated using PTLC with a solvent mixture of hexane:chloroform (3:7). The purified compound was collected and crystallised using hexane and chloroform to give white needles, GRCB 1 (27.7 mg) identified as 5-acetoxyisogoniothalamin oxide (1) an epoxystyryl-lactone which has been previously found in G. sesquipedalis (Hasan et al. 1994).

The chloroform crude extract of the stem (2.34 g) was separated on $\mathrm{CC}$ using a mixture of hexane:ethyl acetate (6.5:3.5). Fractions 61-63 was combined and further separated using PTLC with similar elution system as for the CC and afforded GRDB 5 (white needles). This compound gave $\mathrm{R}_{\mathrm{f}}$ value 0.36 in similar solvent system as for the PTLC. Spectroscopic data showed that GRDB 5 is similar to 5-acetoxygoniothalamin (2) that has been reported from Goniothalamus uvaroides (Fasihuddin et al. 1991).

The methanol crude extract of the stem of G. ridleyi (2.26 g) was separated using column chromatography. A mixture solvent of ethyl acetate and methanol at different ratio was used as eluent and afforded 144 fractions. Fractions 4-9 were combined and further purified using PTLC and a mixture of hexane:ethyl acetate (8:2) as eluting solvent. PTLC separation afforded a pure orange coloured compounds, GRDC 2. Based on the spectroscopic data, GRDC 2 has been identified as dehydrogoniothalamin (3). Compound 3 was previously reported from $G$. umbrosus by Fasihuddin and Din 2002.

The ethyl acetate crude extract of the root (9.57 g) was separated using vacuum liquid chromatography (VLC) with ethyl acetate and methanol as eluent to give a total of 12 fractions. Fraction 1-3 which showed similar TLC was further separated using column chromatography with mobile phase consisted of hexane and ethyl acetate which afforded 178 fractions. Fractions 157-165 was combined and further purified using PTLC and hexane:ethyl acetate (4.5:5.5) as mobile phase. PTLC purification afforded a pure compounds GRAB $6(61.7 \mathrm{mg}$, yellowish oily amorphous) with $\mathrm{R}_{\mathrm{f}} 0.4616$ in hexane:ethyl acetate (1:1). Spectroscopic data indicated that GRAB 6 is identical with 5-hydroxygoniothalamin (4) reported by Goh et al. 1995.

The ethyl acetate crude extract of $G$. ridleyi fruit (1.35 g) was separated using CC and a mixture of hexane, ethyl acetate and methanol as mobile phase which afforded 119 fractions. Fractions 33-40 was combined and further purified using PTLC with solvent system hexane:ethyl acetate (7:3) and afforded GRFB $8(77.1 \mathrm{mg})$ as white crystal. GRFB 8 gave $\mathrm{R}_{\mathrm{f}} 0.30$ in hexane:ethyl acetate $(7: 3)$ as mobile phase. Based on the spectroscopic data, GRFB 8 was identified as goniothalamin (5). The presence of $\mathbf{5}$ was reported in various Goniothalamus spp. by Jewers et al. 1972.

\section{COMPOUND IDENTIFICATION}

${ }^{1} \mathrm{H}$ and ${ }^{13} \mathrm{C}$ nuclear magnetic resonance (NMR) spectra were recorded in $\mathrm{CDCl}_{3}$ using BRUKER spectrometer (600 $\mathrm{MHz}$ for proton and $125 \mathrm{MHz}$ for ${ }^{13} \mathrm{C}$ ). Mass spectrometer (MS) spectra were recorded on Shimadzu GCMS QP5050A. Column chromatography (CC) and vacuum liquid chromatography (VLC) was carried out using Merck Silica gel 60 (230-400 mesh ASTM). Thin layer chromatography (TLC) and preparative thin layer chromatography (PTLC) were performed on Merck TLC Silica gel $60 \mathrm{~F}_{254} 0.25 \mathrm{~mm}$ and detected by UV light ( 254 and $365 \mathrm{~nm}$ ).

\section{RESULTS AND DISCUSSION}

The ${ }^{1} \mathrm{H}$ NMR spectrum of GRCB 1 showed disubstituted epoxide protons $\mathrm{H}-7$ and $\mathrm{H}-8$ at $\delta 3.36(\mathrm{dd}, J=1.8,6.0 \mathrm{~Hz}$, $\mathrm{H}-7)$ and $4.04(\mathrm{~d}, J=1.2 \mathrm{~Hz}, \mathrm{H}-8)$; a methine proton next to an acetate $(\delta 5.43(\mathrm{q}, J=3.0 \mathrm{~Hz}, \mathrm{H}-5)$ and a disubstituted double bond at $\delta 6.27(\mathrm{~d}, J=9.6 \mathrm{~Hz}, \mathrm{H}-3) ; 7.11(\mathrm{dd}, J=5.4$, $9.6 \mathrm{~Hz}, \mathrm{H}-4)$ in conjunction with a lactone with a secondary terminus at $\delta 4.45(\mathrm{q}, J=3.0 \mathrm{~Hz}, \mathrm{H}-6)$. The other phenyl ring for $\mathrm{H}-10, \mathrm{H}-11, \mathrm{H}-12, \mathrm{H}-13$ and $\mathrm{H}-14$ were shown at $\delta$ 7.39-7.28 (m). The methyl group for acetyl compound was observed at $\delta 2.09(\mathrm{~s})$. Based on ${ }^{13} \mathrm{C}$ data, two carbonyl carbons were detected i.e. at $\delta 169.8$ and 161.33 for acetyl and phenyl ring, respectively. Substituted phenyl ring were observed at $\delta 125.73$ (C-10, C-14), 128.78 (C-12) and 128.63 (C-11, C-13). The spectrum showed a disubstituted epoxide carbon at $\delta 57.44(\mathrm{C}-7)$ and $58.19(\mathrm{C}-8), \mathrm{C}-5$ at 62.08 and disubstituted double bond at 124.7 (C-3) and 140.33 (C-4). Mass spectrum showed $m / z .274\left([\mathrm{M}]^{+}, 2\right)$, $258\left([\mathrm{M}-\mathrm{O}]^{+}, 2\right), 216\left(\left[\mathrm{~m} / \mathrm{z} 258-\mathrm{C}_{2} \mathrm{H}_{2} \mathrm{O}\right]^{+}, 2\right), 198([\mathrm{~m} / \mathrm{z}$ $\left.\left.258-\mathrm{C}_{2} \mathrm{H}_{4} \mathrm{O}_{2}\right]^{+}, 2\right), 139$ (100), 107 (100), 91 (100), 65 (40) and $43\left(\left[\mathrm{C}_{2} \mathrm{H}_{3} \mathrm{O}\right]^{+}, 100\right)$. Based on the spectroscopic data and published information (Hasan et al. 1994), GRCB 1 was identified as 5-acetoxyisogoniothalamin oxide (1). ${ }^{1} \mathrm{H}$ NMR spectrum of GRDB 5 gave strong absorption of acetoxy peak at $\delta 2.05$ which appeared as singlet. The spectrum also showed that the olefinic protons at $\delta 6.25$ (d, $J=9.6 \mathrm{~Hz}, \mathrm{H}-3), 6.99$ (dd , $J=5.4,6.0,9.9 \mathrm{~Hz}, \mathrm{H}-4), 6.22$ (dd, $J=6.0,6.6,15.9 \mathrm{~Hz}, \mathrm{H}-7), 6.82(\mathrm{~d}, J=16.2 \mathrm{~Hz}, \mathrm{H}-8)$ and aromatic phenyl ring at $7.35(\mathrm{~d}, J=4.2 \mathrm{~Hz}, \mathrm{H}-10, \mathrm{H}-14)$, 7.34 (t, $J=5.4,7.8 \mathrm{~Hz}, \mathrm{H}-11, \mathrm{H}-13)$ and 7.29 (d, $J=7.8 \mathrm{~Hz}$, $\mathrm{H}-12)$. The presence of $\mathrm{H}-5$ and $\mathrm{H}-6$ were observed at $\delta$ 5.19 (dddd, $J=1.2,3.0,6.6 \mathrm{~Hz}$ ) and 5.37 (dd, $J=3.0,5.4 \mathrm{~Hz}$ ). The ${ }^{1} \mathrm{H}$ NMR spectrum was supported by ${ }^{13} \mathrm{C}$ NMR signal at ठ 162.36 (CO), 121.18 (C-3), 140.69 (C-4), 63.90 (C-5), 79.09 (C-6), 134.90 (C-7), 124.81 (C-8), 135.71 (C-9), 126.80 (C-10, C-14), 128.73 (C-11, C-13), 128.53 (CO) and $20.53\left(\mathrm{CH}_{3}\right)$. Mass spectrum of GRDB 5 showed $\mathrm{M}^{+}$at $m / z 258$ (10). Other peaks were observed at $m / z 216$ ([M $\left.\left.-\mathrm{C}_{2} \mathrm{H}_{2} \mathrm{O}\right]^{+}, 5\right), 198\left(\left[\mathrm{M}-\mathrm{C}_{2} \mathrm{H}_{4} \mathrm{O}_{2}\right]^{+}, 15\right), 175\left(\left[\mathrm{C}_{11} \mathrm{H}_{11} \mathrm{O}_{2}\right]^{+}\right.$, $20), 133(100), 125\left(\left[\mathrm{C}_{6} \mathrm{H}_{6} \mathrm{O}_{3}\right]^{+}, 74\right), 115\left(\left[\mathrm{C}_{9} \mathrm{H}_{7}\right]^{+}, 26\right)$, $84(100)$ and $43\left(\left[\mathrm{C}_{2} \mathrm{H}_{3} \mathrm{O}\right]^{+}, 78\right)$. Based on MS and NMR (proton, ${ }^{13} \mathrm{C}$, HMBC, HMQC and COSY) data and comparison with published information data (Fasihuddin et al. 1991), GRDB 5 was identified as 5-acetoxygoniothalamin (2). The 


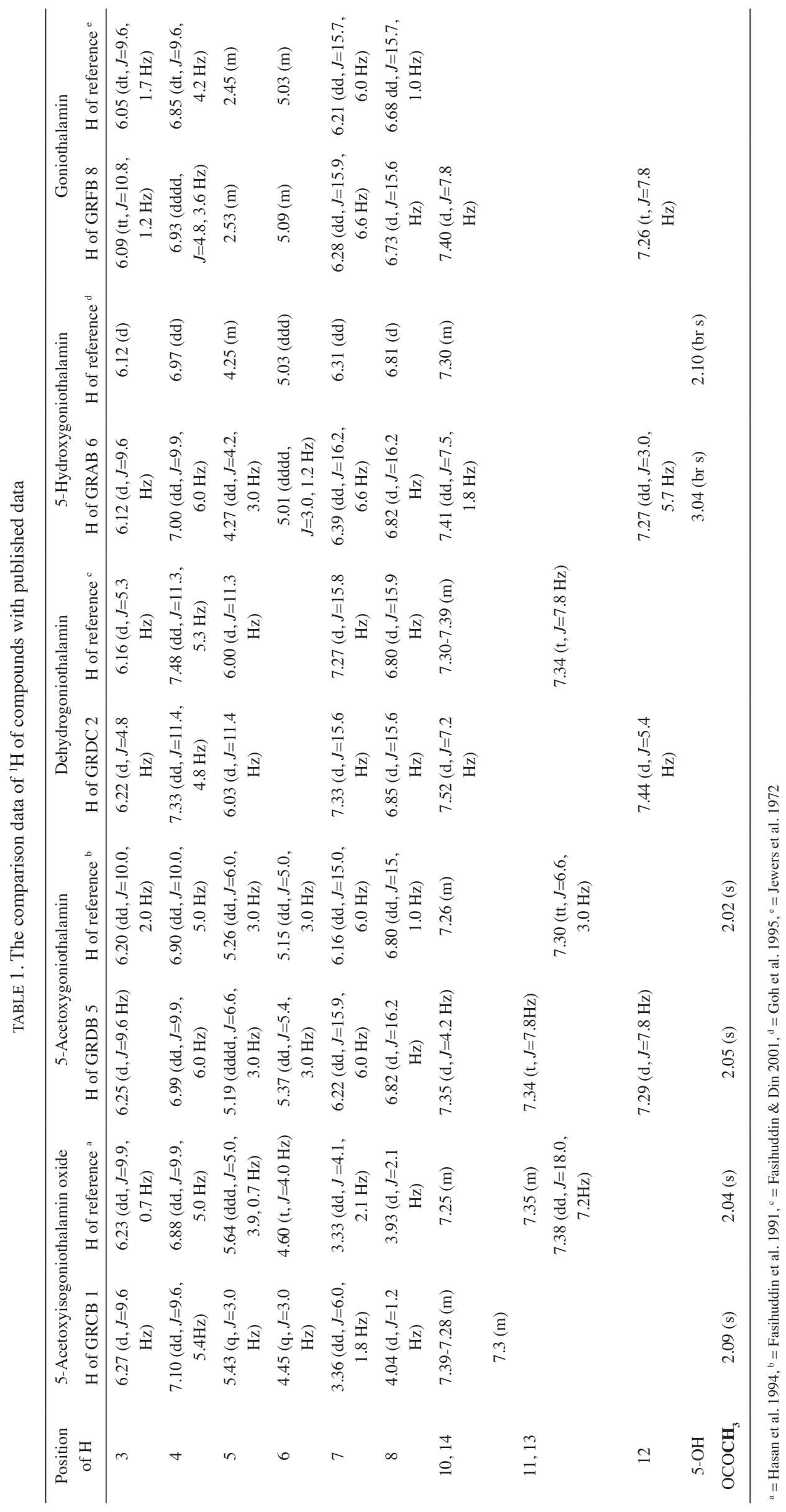




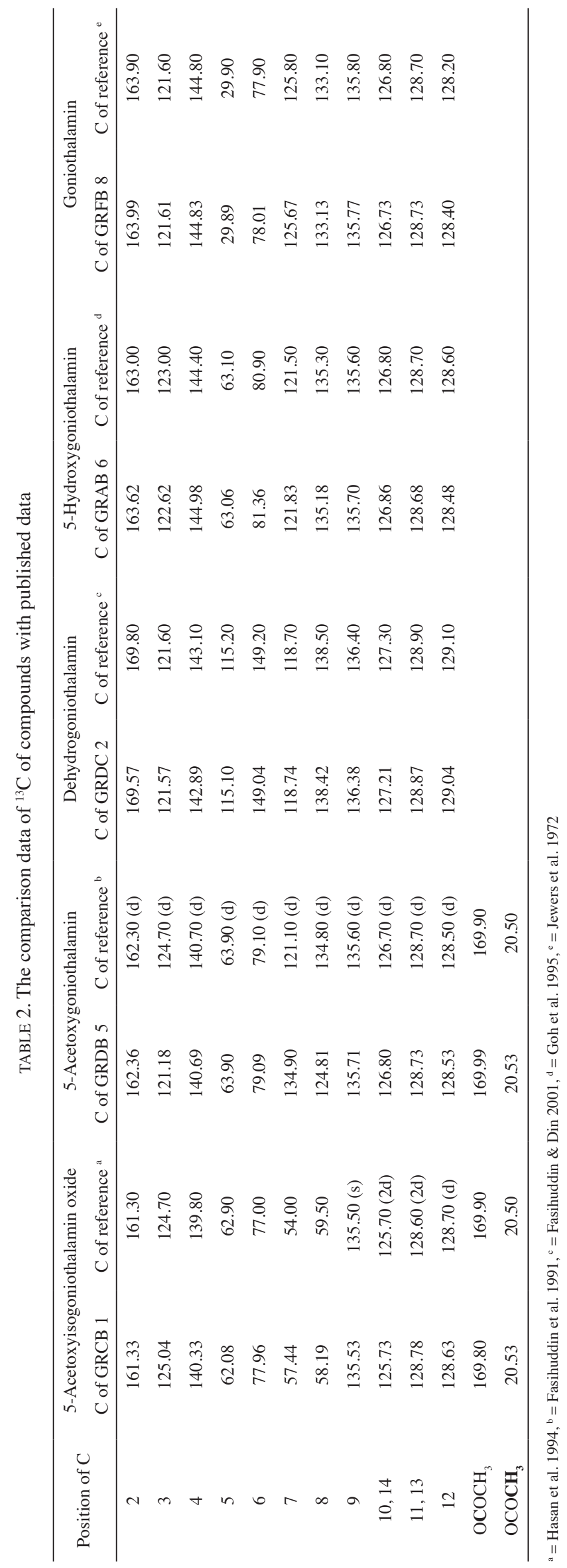


data and comparison of proton and carbon with published data was recorded in Tables 1 and 2, respectively. The different structure of these five styryllactones was recorded in Figure 1.

GRDC 2 was isolated as an orange compound and showed aromatic proton of phenyl ring at $\delta 7.52(\mathrm{~d}, J=7.2$ $\mathrm{Hz}, \mathrm{H}-10, \mathrm{H}-14$ ), 7.38 (dd, J=7.2, 4.2, $18.0 \mathrm{~Hz}, \mathrm{H}-11$, $\mathrm{H}-13)$ and 7.44 (d, $J=5.4 \mathrm{~Hz}, \mathrm{H}-12)$ in ${ }^{1} \mathrm{H}$ NMR spectrum. Two olefinic proton were observed at $\delta 7.33(\mathrm{~d}, J=15.6$ $\mathrm{Hz}, \mathrm{H}-7)$ and 6.85 (d, J=15.6 Hz, H-8). The configuration of these two protons were trans based on their $J$ value i.e. $15.6 \mathrm{~Hz}$. The other protons were observed at $\delta 6.22(\mathrm{~d}$, $J=4.8 \mathrm{~Hz}, \mathrm{H}-3$ ), 7.33 (dd, $J=11.4,4.8 \mathrm{~Hz}, \mathrm{H}-4)$ and 6.03 (d, $J=11.4 \mathrm{~Hz}, \mathrm{H}-5)$. The ${ }^{13} \mathrm{C}$ NMR spectrum showed 13 peaks which represent 13 carbon in GRDC 2 . The carbonyl ester in ring appeared at $\delta 169.57$. The other carbon were observed at $\delta 121.57$ (C-3), 142.89 (C-4) and 115.10 (C$5)$, while aromatic carbon were detected at 136.38 (C-9), 127.21 (C-10, C-14), 128.87 (C-11, C13) and 129.04 (C-12). The olefinic carbon, $\mathrm{C}-7$ and $\mathrm{C}-8$ appeared at $\delta$ 118.74 and 138.42 , respectively. GRDC 2 showed $\mathrm{M}^{+}$and base peak at $\mathrm{m} / \mathrm{z}$ 198. The other peaks were observed $\mathrm{m} / \mathrm{z}$ $170\left([\mathrm{M}-\mathrm{CO}]^{+}, 33\right), 141\left(\left[\mathrm{C}_{11} \mathrm{H}_{9}\right]^{+}, 46\right), 115\left(\left[\mathrm{C}_{9} \mathrm{H}_{7}\right]^{+}, 81\right)$, 89 (10) and 63 (10). Based on the spectroscopic data and published information (Fasihuddin \& Din 2002). GRDC 2 was identified as dehydrogoniothalamin (3).

NMR spectrum of GRAB 6 showed the presence of 11 protons and 12 carbons. Chemical shifts at $\delta 7.41(2 \mathrm{H}, \mathrm{dd}$, $J=1.8,7.5 \mathrm{~Hz}, \mathrm{H}-10, \mathrm{H}-14), 7.30$ (2H, tt, $J=3.0,6.6 \mathrm{~Hz}$, $\mathrm{H}-11, \mathrm{H}-13)$ and $7.27(1 \mathrm{H}, \mathrm{dd}, J=3.0,5.7 \mathrm{~Hz}, \mathrm{H}-12)$ showed the presence of phenyl ring. This is supported by the ${ }^{13} \mathrm{C}$
NMR data which gave signals at $\delta 126.86$ (C-10, C-14), 128.68 (C-11, C-13) and 128.48 (C-12). The hydroxyl group attached to $\mathrm{C}-5$ (63.06) appeared at $\delta 3.04$ (br s). The other signal of four olefinic protons were observed at

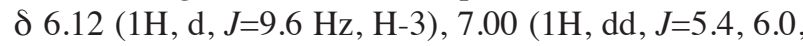
$9.9 \mathrm{~Hz}, \mathrm{H}-4), 6.40$ (1H, dd, $J=6.6,16.2 \mathrm{~Hz}, \mathrm{H}-7)$ and 6.82 $(1 \mathrm{H}, \mathrm{d}, J=16.2 \mathrm{~Hz}, \mathrm{H}-8)$. Signal of H-5 and H-6 appeared at $\delta 4.27(1 \mathrm{H}, \mathrm{dd}, J=3.0,4.2 \mathrm{~Hz})$ and $5.01(1 \mathrm{H}, \mathrm{dddd}, J=1.2$, $3.0 \mathrm{~Hz})$ respectively. The other carbon showed at $\delta 163.62$ (C-2), 122.62 (C-3), 144.98 (C-4), 81.36 (C-6), 121.83 (C7), 135.18 (C-8) and 135.70 (C-9). Based on NMR data and comparison with published data (Goh et al. 1995), GRAB 6 was identified as 5-hydroxygoniothalamin (4).

GRFB 8 as yellowish white needles showed 12 protons and 13 carbons. The NMR ${ }^{1} \mathrm{H}$ spectrum showed $\mathrm{CH}_{2}$ at $\delta$ $2.53(2 \mathrm{H}, \mathrm{m}, \mathrm{H}-5)$ while $\mathrm{CH}$ could be detected at $6.07(1 \mathrm{H}$, dt, $J=1.8,9.9 \mathrm{~Hz}), \mathrm{H}-3), 6.92$ (1H, dddd, $J=3.6,4.8 \mathrm{~Hz}$, H-4), 5.09 (1H, m, H-6), 6.27 (1H, dd, J=6.6, $15.9 \mathrm{~Hz}$, H-7), 6.72 (1H, d, J=16.2 Hz, H-8), 7.39 (2H, d, $J=5.6 \mathrm{~Hz}$, H-10, H-14), 7.17-7.35 (2H, m, H-11, H-13) and 7.26-7.30 $(1 \mathrm{H}, \mathrm{m}, \mathrm{H}-12)$. The NMR ${ }^{13} \mathrm{C}$ spectrum showed $\mathrm{CO}$ at $\delta$ $164.08(\mathrm{C}-2), \mathrm{CH}_{2}$ at $29.86(\mathrm{C}-5)$ and $\mathrm{CH}$ at $121.56(\mathrm{C}-3)$, 144.91 (C-4), 78.03 (C-6), 125.66 (C-7), 133.16 (C-8), 135.77 (C-9), 126.73 (C-10, C-14), 128.72 (C-11, C-13) and $128.39(\mathrm{C}-12)$. MS data of this GRFB 8 observed $[\mathrm{M}]^{+}$at $\mathrm{m} / \mathrm{z}, 200$ and base peak at $\mathrm{m} / \mathrm{z}, 68$ (cyclopentenyl ion). The other peaks were $m / z 172\left([\mathrm{M}-\mathrm{CO}]^{+}\right), 131$ (cinnamyl ion), 122, 115 (indenyl ion), 104 (styrenyl ion), 91 (tropilium ion), 77 (phenyl ion), 51 and 39. The NMR and MS data was compared to Jewers et al. 1972 and it is identical with goniothalamin (5).<smiles>CC(=O)OC1C=CC(=O)OC1C1OC1c1ccccc1</smiles>

(1)<smiles>O=c1cccc(/C=C/c2ccccc2)o1</smiles>

(3)<smiles>CC(=O)OC1C=CC(=O)OC1/C=C/c1ccccc1</smiles>

(2)<smiles>O=C1C=CC(O)C(/C=C/c2ccccc2)O1</smiles>

(4)<smiles>O=C1C=CCC(/C=C/c2ccccc2)O1</smiles>

(5)

FIGURE 1. Styryllactones in G. ridleyi 


\section{CONCLUSION}

Phytochemical studies on G. ridleyi resulted in the isolation of five styryllactone identified as 5-acetoxyisogoniothalamin oxide (1), 5-acetoxygoniothalamin (2), dehydrogoniothalamin (3), 5-hydroxygoniothalamin (4) and goniothalamin (5). Compound 1 was isolated from the chloroform crude extract of the fruit and stem bark; compound 2 from the chloroform crude extract of the stem and the hexane, chloroform and methanol crude extract of the root; compound 3 from the methanol crude extract of the root and stem; compound 4 from the chloroform crude extract of the root and compound 5 from the chloroform crude extract of the fruit. Compound 1-5 were isolated through extensive chromatography especially column chromatography and preparative thin layer chromatography. This is the first report on the isolation of compound 1-4 in G. ridleyi. Hence, this is part of our continuous phytochemical studies on Goniothalamus found.

\section{ACKNOWLEDGEMENTS}

We wish to thank the Ministry of Agriculture and Agrobased Industry (MOA), Malaysian Agricultural Research and Development Institute (MARDI) and UKM Grant (UKM-ST-06-FRGS0110-2009, UKM-GUP-2011-205 and UKM-DLP-2012-033) for the financial support. We would also like to thank Mr. Ujang Suki, Mr. Man Ghani, Mr. Mohd. Nor Ibrahim, Mrs Norfauziana Aziz, Mrs Norliza Abu Baker, Mr. Mohd Zahid Md Yusoff from UKM, Mr. Tengku Rahimi Tuan Mohamad, Mr. Nik Mustafa Azmi Nik Lah, Mr. Faizal Mohamad from Jabatan Perhutanan Jajahan Selatan Kelantan, Kelantan and Mr. Hamzah Mahat, Mr. Abd. Ghani Osman and Ms Siti Salwah Baba from MARDI who have been helping us in collecting sample and analysis compounds.

\section{REFERENCES}

Ee, G.C.L., Lee, H.L. \& Goh, S.H. 1999. Larvicidal activity of Malaysian Goniothalamus species. Natural Product Letters 13(2): 137-142.

Fasihuddin, B.A. \& Din, L.B. 2002. Isolation and characterization of dehydrogoniothalamin from Goniothalamus umbrosus. Indian Journal of Chemistry - Section B Organic and Medicinal Chemistry 41(7): 1540-1541.

Fasihuddin, B.A., Tukol, W.A., Omar, S. \& Sharif, A.M. 1991. 5-acetyl goniothalamin, a styryl dihydropyrone from Goniothalamus uvaroides. Phytochemistry 30(7): 2430-2431.
Goh, S.H., Ee, G.C.L. \& Chuah, C.H. 1995 $5 \beta$-Hydroxygoniothalamin, a styrylpyrone derivative from Goniothalamus dolichocarpus (Annonaceae). Natural Product Letters 5: 255-259.

Hasan, C.M., Mia, M.Y., Rashid, M.A. \& Connoly, J.D. 1994. 5-acetoxyisogoniothalamin oxide, an epoxystyryl lactone from Goniothalamus sesquipedalis. Phytochemistry 37(6): 1763-1764.

Jewers, K., Davis, J.B., Dougan, J. \& Manchanda, A.H. 1972. Goniothalamin and its distribution in four Goniothalamus species. Phytochemistry 11(6): 2025-2030.

Mat-Salleh, K. \& Latiff, M.A. 2002. Tumbuhan Ubatan Malaysia. Bangi: Penerbit UKM. p. 112.

Wiart, C. 2007. Goniothalamus species: A source of drugs for the treatment of cancers and bacterial infections? Evidence-Based Complementary and Alternative Medicine 4(3): 299-311.

\section{Samsiah Jusoh}

Rice and Industrial Crop Research Centre

Malaysian Agricultural Research and Development Institute (MARDI)

P.O. Box 12301, 50774 Kuala Lumpur

Malaysia

\section{Zuriati Zakaria}

Malaysia Japan Institute of Technology

Universiti Teknologi Malaysia

54100 Kuala Lumpur

Malaysia

Fasihuddin B. Ahmad

Department of Chemistry

Faculty of Resource Science and Technology

Universiti Malaysia Sarawak

94300 Kota Samarahan, Sarawak

Malaysia

Samsiah Jusoh \& Laily B. Din*

School of Chemical Sciences and Food Technology

Faculty of Science and Technology

Universiti Kebangsaan Malaysia

43600 Bangi, Selangor Darul Ehsan

Malaysia

*Corresponding author; email: lbdin@ukm.edu.my

Received: 4 October 2013

Accepted: 4 September 2014 